Vol. 2 No. 3, December 2020 - March 2021, pp. 20 - 25

\title{
FACTORS AFFECTING STUDENTS IN TRANSLATING TEXTS IDIOMATICALLY
}

\author{
Morada Tetty \\ Universitas Negeri Medan \\ tettymorada@gmail.com
}

\begin{abstract}
The discussion of translation used by students has been investigated long time ago in which the setup of the Second Language Development was firstly established, i.e around 1900s. Many Error Analyses on translation have been analyzed by linguists which become the valuable contributions towards the study of translation.

This study deals with error analysis of students' project on translations of English Department of UNIMED so that there could be drawn some factors that make students are in difficulty in translating texts idiomatically. Qualitative method is used in analyzing this study and all the data are taken from students' projects and worksheets on translation.

Among factors that cause students are in difficulty in translating texts idiomatically are less understanding the meanings of the texts, do not fully master the lexicogrammar, do not understand the language concepts, social context, language use, etc.
\end{abstract}

Keywords : Translating texts idiomatically, Error Analysis, Second language Acquisition, First language (L1), Second Language (S2)

\section{Introduction}

Theories on Error Analysis (EA), Contrastive Analysis (CA) and Second Language Acquisition (SLA) are the most valuable and significant works in describing language learner. The study of errors is carried out by means of EA, where in 1970s, EA supplanted CA which sought to predict the errors that learners make by identifying the linguistic differences between their L1 and the target language. Meanwhile, SLA investigates the development of $L 1$ or $L 2$ acquisitions or about explaining the psycholinguistics processes 
Vol. 2 No. 3, December 2020 - March 2021, pp. 20 - 25

that underlie L2 acquisition and use, the attention to social factors that influence development and so on. Many theories on those sciences have provided researchers with evidences of how language is learnt, how much the learner has learnt, learner language development etc.

The field of Error Analysis is closely associated with the work of Corder, who published a number of seminal articles in the 1960s/1970s, in which he made out a case for examining errors as a way of investigating learning processes. He also helped to develop a methodology for carrying out an error analysis. Ellis (1994:19).

One of the first subjects that applies the error analysis is Translation Others are Syntax, Phonology, Morphology and Semantics. Some studies of EA on translation are such as the work of Lee (1957) as quoted by Ellis (1994:48) says errors in the written work of Czechoslovakian learners, which were grouped into categories (wrong punctuation, misuse, or omission of articles, misspellings, non-English constructions and wrong use of tenses).

Lococo (1976) quoted by Ellis (1994:50) says errors reflecting L1 influence were, not surprisingly, more common in the translation task.

Translation products as manifestation of transferring meanings from a source language into the receptor language could also be potentially infected with many errors especially when the translators are still inexperienced learners i.e learners who have no adequate knowledge.

This study analyzes errors made by students of English Department of UNIMED in their translation projects given by the lecturer during the lecture course, so that there could be known the characteristics of students' errors, the causes and thus can be taken some solutions in preventing students from making the errors. 
Vol. 2 No. 3, December 2020 - March 2021, pp. 20 - 25

\section{Findings}

\section{Factors affecting students in translating texts idiomatically}

Based on analyzing, observing and correcting the students' translation projects, students' worksheets, exam papers and any routine tasks, the very most dominant factors that cause the students to translate texts non idiomatically, are as follows:

\section{Less understanding the meanings of the texts.}

Understanding for a complete meaning of the text is absolutely needed to produce a communicative translation. This is related to knowing the background of the texts, what kinds of texts they are (genre), when and where the texts are written, who writes it or who are the writers, what the topics are about and any correlations of the topics to other fields, etc. Especially for some kinds of literary texts that needs further exploration towards the intended meaning/speaker meaning, more explorations to the figurative meanings, symbols, etc, Thus, when students neglect this aspect, the translated texts would not achieve the appropriateness between the source texts into the target ones, and will not be regarded as idiomatic texts.

Some clear examples of the students' techniques to translate the texts are by translating directly word by word, sentence by sentence of the texts. Thus, the translated texts will sound unnatural and not acceptable in the target language.

\section{Do not fully master the lexicogrammar}

The most common errors students/learners usually make in translating their L1 into L2 (English) is about wrong grammar/lexicogrammar. This also happen to the students in English department of UNIMED in translating their texts. The lack of knowledge of English grammar, such as tenses, the use of prepositions, wrong spellings, concordances, dictions, how to correlate sentence by sentence in a good coherence, even pluralization as regarded as one of the easiest points in English, sometimes still exist in their translated texts. 
Vol. 2 No. 3, December 2020 - March 2021, pp. 20 - 25

\section{Do not understand the language concepts, social contexts, and language use.}

Insufficient knowledge of Language in general, specifically English horizons is also the main reason for students/learners to produce a natural and acceptable translated text. Thus, when we are not equipped with abundant knowledge about English horizons, this might result in a non-communicative text. As in Bahasa Indonesia, English also has a system for its word order, pronunciations, grammatical points, language concepts, language use, and many more which are different from Bahasa Indonesia. We really need to consider these aspects when translating texts from $L 1$ into $L 2$ or vice versa.

\section{L1 Influences.}

For inexperienced students/learners, making L1 transfer/influences into their translated texts (L2) is also very common. It ranges from the word choices, word order, naturalness in the target language, etc. Students usually transfer their L1 concepts into the translated the texts. This result in the unnaturalness of the target language. Students tend to use their prior knowledge on languages and apply them to the target language. In other words, students/learners may also tend to use the same patterns of language they know because of habit, and apply them to the target language.

\section{Direct Instruction.}

Students/learners usually have less ability to direct instructions for performances. It means students/learners' mental knowledge are not open to direct instruction compared to guided ones. They are better to guided instructions than spontaneous ones. So, when they are asked to translate texts in spontaneous settings, their performances in the translated texts are worse than in guided ones. 
Vol. 2 No. 3, December 2020 - March 2021, pp. 20 - 25

\section{Conclusion}

In conclusions, this literature review on students' tasks, worksheets, and translation projects over the lecture course, has drawn some conclusions on factors that affect students' texts idiomatically such as; less understanding the meanings of the texts, do not fully master the lexicogrammar, do not understand the language concepts, social contexts, and language use, use transfer/influences, and less capability in direct instructions/setting. It is hoped that more educational teachers/instructor will seriously consider these factors in their English learning/teaching processes in order to achieve a better improvement towards the students' language competence and performance.

\section{Discussion}

From the five points above, students of English Literature, UNIMED also made the same mistakes in producing their translated texts. For point 1 (less understanding the meanings of the texts), the data obtained such as; there was hardly anybody on the beach, it was almost deserted > tidak ada orang di pantai itu, pantai itu hampir menjadi padang pasir. This translated text could be easily understood wrong because the meaning of almost deserted here is nyaris ditinggalkan. Thus, the accepted translation should be hampir tidak ada orang di pantai itu, pantai itu nyaris ditinggalkan. For point 2 ( do not fully master the lexicgrammar), the data got such as; if there are any words you don't understand, use a dictionary > jika ada beberapa kata yang tidak kamu pahami, gunakanlah kamus. This translated text was grammatically incorrect, because the word any was translated into beberapa. While grammatically any meant it doesn't matter, which words you don't understand. The natural Indonesian should be Jika ada kata kata yang tidak kamu pahami, gunakanlah kamus. For point 3 ( do not understand the language concepts, social contexts, and language use), it was found; when I told him I won a prize at a lottery he called me a lucky dogs ketika aku memberitahukannya bahwa aku memenangkan hadiah lotere, dia menyebutku anjing yang beruntung. It is not translated idiomatically for a lucky dog should be translated orang yang beruntung. For point 4 
Vol. 2 No. 3, December 2020 - March 2021, pp. 20 - 25

(influences), the finding is; nowadays, many people are busy with their media social. It should be ... social media. Finally for point 5 ( direct instruction), the finding is; when the students were asked to translate to achieve 'World Class Company' through Professional Image... in a spontaneous way, it was found just a few of them that could translate it idiomatically. Many were in difficulties to do it. A finding of unnatural translation was > untuk mencapai perusahaan kelas dunia adalah dengan kesan profesional. It was wrongly translated because it was from a phrase which was translated into a complete sentence. It should be untuk mendapatkan julukan 'perusahaan kelas dunia' melalui kesan profesional ... However, specifically for point 5 , there should be further analysis and research to really proven this argument, especially for students of English department of UNIMED, Medan.

\section{References}

Brown, H.D. 1987. Principles of Language Learning and Teaching. New Jersey: Prentice Hall, Inc.

Corder, S.P. 1981. Error Analysis and Interlanguage. Oxford : Oxford University Press.

Ellis, Rod.1994. The study of Second Language Acquisition. Oxford: Oxford University Press.

Ellis, Rod. 2005. Principles of Instructed Language Learning. Asean EFL Journal. Vol. 7, Issue 3.

Larson, Mildred, L. 1984. Meaning Based Translation. A guide to cross language equivalence. Boston : University Press of America Inc. 